\title{
EUHARISTIA ȘI DIMENSIUNEA EI HRISTICĂ
}

\section{Andrei-Gabriel COSTACHE ${ }^{1 *}$}

\begin{abstract}
The Eucharisty and her hristic dimension ${ }^{2}$. The religious experience states the possibility that people can participate to the life in communion with God. Our admission to God isn't limited to some extemal forms, but involves the entire psychophysical being. This participation gains new dimensions by understanding the Holy Eucharist as the Sacrament of Christ, which gives us the eternal life - „But if you do eat my flesh and drink my blood, you will have eternal life" (John 6,54) -, and also as a Mystery of the knowledge of God - Eternal life is to know you, the only true God, and to know Jesus Christ, the one you sent (John 17,3). Thus, the knowledge isn't only the urge to which the Christian must adhere, but it postulates a conscious involvement which helps to understand the meaning of the Sacrament. In the beginning, the Eucharistic ritual, being short and simple, didn't need an explanation, because it was the centre of the cult and of the entire religious life of the Church. The Holy Eucharist started to be a subject of debates, study or explanation when the first misinterpretations about its internal idea, or its external form appeared. Therefore, the first explanations of the Holy Eucharist appeared in the writings of the Apologists. These misinterpretations are still present today, as a reminiscence of the past, in different sectarian environments. As a result, we, as exponents of the Orthodoxy, having theduty of confessing the teaching of Christ, must defend our faith from the attacks of those who do not believe in the Holiness of the Eucharistic preface. Through the miraculous preface of the Eucharistic gifts in the Flash and Blood of the Lord it is realised, in a mystical form, the great mystery of the Christianity (cf. 1 Timothy 3,16 ): the incarnation of the Lord. Therefore, the Eucharistic preface is a new and miraculous incarnation of God, with every Liturgy. In
\end{abstract}

*Diacon, PhD Student, Faculty of Orthodox Teology „Justinian Patriarch”, at University of Bucharest, Bucharest, Romania.

${ }^{2}$ Studiu realizat sub îndrumarea Pr. Prof. Univ. Dr. Constantin Pătuleanu, care și-a exprimat acordul pentru publicare. 
other words, The Holy Eucharist is an extension in time of the Incarnation, a mystical immortality for us.

Keywords: Holy Eucharist, sacrament, preface, Jesus Christ, offering, Holy Fathers, the Flash and Blood of the Lord.

\section{Introducere}

Cuvântul euharistie provine din limba greacă, de la verbul care înseamnă $a$ mulţumi, folosit de Mântuitorul, Care instituind această Sfântă Taină, mai întâi a mulţumit lui Dumnezeu şi după aceea a binecuvântat pâinea pe care, frângând-o, a dat-o Sfinţilor Apostoli zicând: „Luaţi, mâncaţi, acesta este Trupul Meu. Şi luând paharul şi mulţumind, le-a dat zicând: Beţi dintru acesta toţi, că acesta este Sângele Meu, al Legii celei noi, care pentru mulţi se varsă spre iertarea păcatelor" (Mt. 26, 26-28) .

Sfânta Euharistie este numită Taină deoarece acest termen este traducerea substantivului grecesc misterion. După cum se ştie, termenul - misterion - înseamnă lucru tăinuit, ascuns, secret, ceva ce nu poate fi cuprins cu mintea, o învăţătură tainică, așa cum aflăm în scrierile tardive ale Vechiului Testament (Înţelepciunea lui Solomon, Inţelepciunea hi Iisus Sirah, Tobit, Iudita). În Noul Testament, acest termen se referă mai ales la planul lui Dumnezeu de mântuire a lumii (Rom. 16, 25-26; I Cor. 2, 7-9). Planul dumnezeiesc de mântuire s-a realizat deplin în Iisus Hristos, Care este prin excelenţă Taina lui Dumnezeu - Tatăl (Col. 2, 2). Instituitorul Sfintelor Taine şi adevăratul lor săvârşitor este Iisus Hristos, deoarece harul, care ni se împărtăşeşte în mod nevăzut prin Sfintele Taine, nu este altceva decât lucrarea lui Hristos. Fiul lui Dumnezeu Îşi continuă lucrarea mântuitoare în Biserică, prin revărsarea harului Duhului Sfânt în Sfintele Taine. În sușirea eclesiologică a Sfintelor Taine presupune nu numai faptul că acestea înfăptuiesc Biserica, ci şi faptul că Tainele aparțin Bisericii, că doar Biserica le poate săvârşi, prin slujitorii ei: episcopi, preoţi şi diaconi. Puterea de a învăţa, de a sfinți şi de a conduce pe credincioşi la mântuire (In. 20,21-23; Mt. 28, 18-20; Mc. 16, 15-16) a fost dăruită în mod direct de către Mântuitorul Sfinţilor

${ }^{3}$ Ioasaf GANEA, ,,Taina Sfintei Euharistii, mijloc de mântuire”, în Mitropolia Moldovei şi Sucevei, nr. 5/1988, p. 67. 
Apostoli, iar apoi, prin aceștia, urmaşilor lor, episcopilor şi preoţilor, aceştia fiind investiți cu puterea Duhului Sfânt pentru slujirea de iconomi ai Tainelor lui Dumnezeu (I Cor. 4, 1$)^{4}$.

Studiul de față se dorește a fi o scurtă analiză și prezentare a Sfintei Euharistii ca Sfântă Taină, în vederea dobândirii vieții veșnice la care trebuie să tindă toți oamenii. De asemenea, dorim să evidențiem câțiva Sfinți Părinți care au făcut referire la Euharistie, să prezentăm materia folosită la Sfânta Euharistie și simbolistica acesteia și să încercăm să explicăm modul în care pâinea și vinul se prefac în Sfântul Trup și Sânge al Domnului nostru Iisus Hristos.

\section{Prefacerea Sfintei Euharistii în gândirea Sfinților Părinți}

Chiar și după înviere, Euharistia a fost săvârşită pe pământ, de Hristos, ca o expunere vizibilă a stării Lui de aducere permanentă a Sa în planul nevăzut (Lc. 24, 30-31).

Marea taină a smereniei creştine, arătarea Domnului în Trup, despre care face referire Sfântul Apostol Pavel (I Tim. 3, 16), se realizează în chip mistic prin prefacerea minunată a darurilor euharistice în Trupul şi Sângele Său. Prin urmare, cu fiecare Liturghie a lui Dumnezeu - Cuvântul, prefacerea euharistică reprezintă o nouă întrupare. Euharistia este o prelungire în timp a întrupării, o înveşnicire mistică a ei pentru noi ${ }^{5}$. Prin aceasta se înfăptuiește îndumnezeirea noastră, despre care dă mărturie Sfântul Atanasie al Alexandriei atunci când afirmă că El (Cuvântul) S-a făcut om, tocmai pentru ca noi să ne îndumnezeim. Cu alte cuvinte, prin această continuă şi tainică întrupare euharistică, Fiul lui Dumnezeu Se face pe Sine necontenit Fiul Omului,pentru ca noi să putem deveni fii ai lui Dumnezeu ${ }^{6}$.

În mod analogic, Sfântul Ioan Damaschin realizează o explicare a prefacerii ca lucrare a Duhului Sfânt, prin întruparea Fiului lui Dumnezeu, afirmând că Sfântul Prooroc Isaia a văzut un cărbune aprins. Așa cum cărbunele nu este o substanţă obişnuită, ci una unită cu focul, tot astfel,

${ }^{4}$ Ioan MihăLCESCU, Dogmatica iubirii, col. „Clasici ai teologiei româneşti”, Bucureşti, Edit. România Creștină, 1998, p. 449.

5 NiCOLAE al Makariopolei, „Preînchipuiri euharistice, caracterul şi importanţa lor”, în Mitropolia Banatului, nr. 1-3/1974, p. 34.

${ }^{6}$ Ibidem. 
pâinea împărtăşaniei nu reprezintă o simplă pâine, ci una unită cu divinul, nu printr-un proces de întrupare, ci prin asimilarea în Trupul lui Hristos ${ }^{7}$.

Întâlnirea cu Hristos în Euharistie rămâne lăuntrică, tainică, cu toate că, după Înviere, fiecare apariţie a Sa a fost personală și vizibilă.

Dumnezeu Îşi manifestă dragostea faţă de noi prin întrupare, mai mult chiar decât în actul creației, căci în timp ce atunci ne crea pe noi după chipul Său, aici Se uneşte cu noi, luând chipul nostru ${ }^{8}$. Cu privire la supunerea Fiului față de Tatăl, în toată lucrarea de mântuire a noastră, a vorbit Fiul Însuşi încă înainte de a Se întrupa, prin cuvântul inspirat al psalmistului, după cum ne certifică Sfântul Apostol Pavel: „Drept aceea intrând în lume zice: Jertfă şi prinos n-ai voit, dar mi-ai întocmit un trup. Atunci am zis: iată vin ca să fac, Dumnezeule, voia Ta"(Evr. 10, 5-7; Psalm $39,9)^{9}$. Ceea ce justifică și motivează existența întrupării vine de la Dumnezeu, din dorinţa Sa de a Se face om şi de a face din firea Sa umană, consubstanţială tuturor, o teofanie, locul unde sălăşluieşte Sfânta Treime ${ }^{10}$.

La momentul prefacerii Sfintei Euharistii, preotul, aflat în fața Sfintei Mese, solicită prin rugăciune coborârea Duhului Sfânt de la Tatăl, căci prin Acesta, Tatăl Însuşi preface pâinea şi vinul în Trupul şi Sângele Hristosului Său. Chiar dacă pâinea şi vinul se prefac în Trupul şi Sângele Lui, prefacerea nu este o lucrare numai a lui Hristos, după cum nici nu Sa întrupat fără voinţa Tatălui şi fără lucrarea Duhului în Fecioara Maria.

Astfel, întruparea Cuvântului este o taină mai mare, mai profundă decât facerea lumii ${ }^{11}$ şi este actualizată prin Sfânta Euharistie.

\section{Adevărata hrană veșnică: Sfânta Euharistie}

Încă în cele mai vechi scrieri a fost reflectată concepția cu privire la Sfânta Euharistie ca hrană şi băutură a nemuririi: Didahia celor doisprezece Apostoli (cap. 9 şi 10), Apologia I a Sfântului Iu stin

${ }^{7}$ Olivier Clement, Puterea credinţei, traducere de Alexandrina Andronescu şi Daniela Ciascai, Târgovişte, Edit. Pandora, 1999, p. 161.

${ }^{8}$ Ibidem, p. 306.

${ }^{9}$ Ibidem, p. 104.

${ }^{10}$ Paul Evdochimov, Cunoaşterea lui Dumnezeu în tradiția răsăriteană, traducerea, prefața și notele de Vasile Răducă, Bucureşti, Edit. Christina, 1995, p. 31.

${ }^{11}$ Vladimir Lossky, Teologia mistică a Bisericii de Răsărit, traducere de Vasile Răducă, București, Edit. Bonifaciu, 1998, p. 141. 
Martirul (cap. 66) $)^{12}$. Folosind prin analogie hrana obişnuită, se poate arăta cum se dobândeşte viaţa veşnică prin consumarea Trupului şi Sângelui Domnului. Astfel, hrana materială, fiind produsul pământului, al luminii şi al căldurii solare, al aerului şi al umezelii, prin procesul complex al mâncării (mestecare, dizolvare, absorbţie şi asimilare) şi prin respiraţie (ardere), preface elementele constitutive ale organismului, menţinând în această manieră viaţa acestuia. Organismul viu comunică într-un mod sau altul cu materia şi viaţa prin intermediul hranei, ajungând la o identificare a celui ce se hrăneşte cu lumea materială. Astfel, în Sfânta Euharistie primim sub forma pâinii şi a vinului, adevăratul Trup şi Sânge al lui Hristos, devenim comunicanţi cu esenţa dumnezeiască umană a Domnului şi ne facem asemenea Lui, sfinţindu-ne şi primind mărturia sau chezăşia nemuririi. Şi, după cum prin întrupare Fiul lui Dumnezeu S-a făcut asemenea nouă, după firea Sa omenească, tot aşa şi noi, prin consumarea Trupului şi a Sângelui Său dumnezeiesc, devenim asemenea Lui ${ }^{13}$.

Teodor de Mopsuestia afirmă că pentru a rămâne în această viaţă, luăm ca hrană pâinea care are puterea să menţină în noi viaţa, pentru că Dumnezeu i-a dat această putere, în mod asemănător noi primim nemurirea, mâncând pâinea cea de taină. Dacă hrana trupească se schimbă înlăuntru în izvorde viaţă, adicăpâinea, peștele şi orice mâncare se prefac în sânge hrănitor, în Împărtăşanie lucrurile se întâmplă total opus, în sensul în care, însăşi Pâinea v ieţii schimbă, preface şi umple de viaţă pe cel ce se împărtăşeşte, intrând până în minte şi în inimă, prin această Pâine ne mişcăm şi vieţuim, fiind singura care are viaţă întru sine ${ }^{14}$.

Fiind Absolutul transcendent, Hristos nu Se preface în momentul în care Se oferă ca hrană omului, ci El este Cel ce îl transformă pe om în ceea ce este El Însuşi, la fel cum hrana se transformă în interiorul omului care o mănâncă (pâinea, peştele, vinul şi orice alt aliment se transformă în sânge omenesc). Cu toate acestea, în Euharistie se întâmplă contrariul: însăşi Pâinea Vieţii mişcă pe cel ce se hrăneşte și-l schimbă, îl preface în Ea însăşi. În acest fel, omul devine mădular

12 NiCOLAE al Makariopolei, „Preînchipuiri euharistice, caracterul şi importanţa lor”, p. 33.

${ }^{13}$ Ibidem, p. 34.

${ }^{14}$ Nicolae CABAsila, Despre viaţa în Hristos, traducere din limba greacă şi note de Teodor Bodogae, Bucureşti, EIBMBOR, 1997, p. 109. 
efectiv al Trupului lui Hristos, mădular hrănit şi făcut viu de Cap, "fiindcă cele ale capului cu necesitate coboară la trup" ${ }^{15}$. În Taina Sfintei Euharistii omul primeşte în mod substanţial Trupul omniunic al lui Hristos, în care locuieşte deplinătatea dumnezeirii, unindu-se cu El în mod substanţial, deşi într-un mod nevăzut.

La Cina Domnului, Hristos dizolvă în noi realitatea cerească a Trupului Său, în chipul pâinii şi al vinului, iar omul devine o părticică a firii îndumnezeite a lui Hristos ${ }^{16}$.

Așadar, acestea fiind spuse, se ridică o întrebare: De ce au fost alese tocmai mâncarea şi băutura ca mijloace de comunicare cu Dumnezeu şi de dobândire a vieţii veşnice? Răspunsul este: Pentru că tot prin mâncare am pierdut darul vieţii celei de veci (Fac. 2, 17; 3, 3). Continuând firul întrebării: Dar, de ce tocmai pâinea şi vinul au fost alese să devină Trupul şi Sângele Domnului? Răspunsul este: Pentru că acestea constituie hrana de bază a omului (Mt. 6, 11), iar Mântuitorul însuşi S-a numit pe Sine pâine cerească, pâinea vieţii (In. 6, 32). Nu întâmplător Domnul Iisus S-a născut în Betleem, oraş a cărui denumire înseamnă în evreieşte casa pâinii.

Simbolul unităţii noastre cu Hristos şi cu Biserica Sa este pâinea, reprezentând, totodată, rezultatul adunării într-una a boabelor multe de grâu, împrăş̧iate prin lanuri (Didahia - cap. 10), iar vinul, mai ales cel de culoare roşie, este simbolul sângelui omenesc (Fac. 4-9, 11) şi, îndeosebi, al Sângelui răscumpărător al Domnului ${ }^{17}$.

Prin actualizarea venirii lui Hristos în Euharistie, Biserica devine laudă Domnului şi dar pentru toată lumea, din partea întregii lumi, pentru că prin aceasta suntem prefăcuţi nu numai noi în Hristos, ci şi raţiunile lumii pe care Hristos a vrut să le adune în Trupul Său, prin trupurile noastre ${ }^{18}$.

Sfântul Maxim Mărturisitorul consideră că unirea cu Hristos prin cugetare pregătește unirea cu Hristos prin Euharistie. Prin îndreptarea gândirii credincioase - metanoia - a comunităţii spre Hristos se preface şi raţiunea pâinii în Trupul lui Hristos, căci întoarcerea raţiunilor spre

\footnotetext{
15 Ibidem, p. 158.

${ }^{16}$ Ibidem, p. 101.

${ }^{17}$ NiCOLAE al Makariopolei, ,,Preînchipuiri euharistice, caracterul şi importanţa lor”, p. 33.

${ }^{18}$ Dorel Pogan, ,,Semnificaţia eclesiologică a Sfintei Euharistii”, în Studii Teologice, nr. 7-8/1973, p. 541.
} 
Logos are loc prin om ${ }^{19}$. În Sfânta Taină a Euharistiei, Hristos este descoperit ca viaţă şi recapitulare a întregii creaţii ${ }^{20}$.

\section{3. Înțelegerea prefacerii Sfintei Euharistii}

Viața spirituală a credincioșilor este desăvârșită prin hrănirea cu Sfânta Euharistie, care îi uneşte în chip tainic cu Hristos. Aceasta este pentru suflet ceea ce este hrana materială pentru trup. „Trupul Meu este adevărată mâncare, şi Sângele Meu, adevărată băutură” (In. 6, 56). După cum hrana materială modifică trupul în care intră, Sfânta Euharistie schimbă, desăvârşind, întreaga fiinţ̧ă a celui care o primeşte cu vrednicie, făcându-1 asemenea cu Hristos, adică ,părtaş dumnezeieştii firi” (II Ptr. 1, 14). Dimensiunea hristică a Euharistiei este aceea a îndumnezeirii omului, idee pe care o susține însuşi Sfântul Atanasie prin faptul că El (Cuvântul) S-a făcut om pentru ca noi să fim părtași îndumnezeirii, fiindcă ne dă Trupul şi Sângele Său cu putere dumnezeiască; Sfânta Împărtăşanie este una din căile de obţinere sau, mai bine spus, ale modului de asimilare al nemuririi. Prin Euharistie, puterea dumnezeiască nu se sfârșește la graniţa morţii, ci lucrează în continuare prin suflet. Iar Sfântul Chiril al Ierusalimului îi denumește pe cei ce se împărtășesc, hristofori.

Unirea noastră personală cu Mântuitorul se realizează prin Euharistie. Această unire ne menţine viața personală şi responsabilă în faţa lui Dumnezeu şi ne oferă opţiunea de a spori permanent în Hristos, Dumnezeu întrupat. Fiecare împărtăşire reprezintă o inedită intâlnire, legătură şi unire cu Hristos Dumnezeu, o ascensiune importantă în întâlnirea şi comuniunea cu Hristos Însuşi şi cu aproapele nostru, ca împreună mădulare ale lui Hristos. De vreme ce prin Botez şi Mirungere oamenii ajung să fie frați ai Mântuitorului şi fii ai Tatălui ceresc, prin Sfânta Euharistie „,nu mai trăiesc eu, ci Hristos trăieşte în mine” (Gal. 2, 20). Trupul lui Hristos Însuşi, împreună cu puterea Lui care a surpat moartea şi care e transfigurat de înviere ${ }^{21}$ ne sunt transmise prin

${ }^{19}$ Dumitru StĂniloae, ,Teologia Euharistiei”, în Ortodoxia, nr. 3/1969, p. 349.

${ }^{20}$ Ioannis Zizıoulas, Fiinţa eclesială, traducere de Aurel Nae, Bucureşti, Edit. Bizantină, 1996, p. 128.

${ }^{21}$ Ion StolcA, „Unirea credinciosului cu Hristos prin Sfintele Taine”, în Mitropolia Moldovei şi Sucevei, nr. 3-6/1979, p. 288. 
împărtăşanie. Unirea omului credincios cu Hristos, prin Sfintele Taine, este în mod surprinzător atât stabilă, cât şi dinamică, deoarece Sfântul Grigorie de Nyssa ne îndeamnă să urcăm permanent în cele duhovnicești, altfel nu rămânem nici măcar unde ne aflăm.

Hristos continuă să trăiască în Biserică prin Sfânta Liturghie, iar noi ne transformăm în adevăraţi martori ai evenimentelor mântuitoare, luând parte la Taina Împărătiei lui Dumnezeu ${ }^{22}$, care este Euharistia.

In cadrul fiecărei Liturghii, toţi credincioșii sunt aşezaţi în jurul Agneţului (Mielul de Jertfă), sub formă de miride, fiind integraţi în Jertfa Sa. În momentul în care o miridă este scoasă dintr-o prescură specială şi este pronunțat numele unei persoane, acea persoană este oferită în jertfă lui Dumnezeu, fiindu-i iertate păcatele, intrând în harul luminos care izvorăşte din mormântul Mântuitorului, în viaţa transfigurată şi îndumnezeită pentru care a fost creată.

Părintele Dumitru Stăniloae afirmă că prin intermediul Tainelor are loc „,unirea lui Dumnezeu cu creatura”, prin faptul că Mântuitorul pătrunde cu Trupul Său, cu energiile Trupului Său preamărit, în trupul nostru. În consecință, Sfintele Taine sunt căi prin care Dumnezeu ne sfinţeşte. Prin slujbele ortodoxe se sfinţesc nu doar sufletele oamenilor, ci întreaga lume, dat fiind faptul că actul sfinţitor al Duhului Sfânt se revarsă prin Biserică asupra întregii naturi. Soarta naturii, fiind relaționată de soarta omului, din cauza căruia suferă stricăciunea, îşi găseşte dezlegarea şi restaurarea tot împreună cu omul. Hristos Îşi dă Trupul ca pâine, iar Sângele Său dătător de viaţă îl oferă ca vin, aşadar prin cele materiale.

Lumea interioară a credinţei este lumea Sfintelor Taine. În această privință, Sfântul Chiril al Ierusalimului ne învaţă să nu privim la pâine şi vin, ca la pâinea şi vinul obişnuit, deoarece ele, potrivit hotărârii Stăpânului, sunt Trup şi Sânge al lui Hristos ${ }^{23}$. Toate minunile văzute ale Mântuitorului, de la prefacerea apei în vin la Cana până la înmulţirea pâinilor şi de la Schimbarea la Faţă până la învierea lui Lazăr, i-au pregătit

22 Ioan ANDreicuȚ, „Pietismul sectant - îndepărtarea de la credinţa creştină”, în Ortodoxia, nr. 1/1989, p. 63.

23 Sfântul CHIRIL al Ierusalimului, Catehezele, traducere de Dumitru Fecioru, București, EIBMBOR, 1943, p. 356. 
pe Sfinţii Apostoli şi, desigur, pe toţi credincioşii pentru primirea minunilor ascunse în Sfintele Taine ${ }^{24}$.

Omul este făcut pentru o veşnicie cu Dumnezeu și nu pentru un timp trecător, timpul servindu-i numai ca drum spre viața veșnică ${ }^{25}$. De aceea, Dumnezeu S-a făcut om, ca omul să ia parte la viaţa dumnezeiască (II Ptr. 1, 4) prin Duhul Sfânt, Care a umplut prin înviere umanitatea Mântuitorului. Fiul S-a întrupat întru totul asemenea nouă, în afară de păcat, ca noi să devenim asemenea Lui, prin îndumnezeirea lucrată în noi după înviere, dar cu încuviințarea şi strădaniile noastre. Această lucrare mântuitoare se înfăptuiește în Biserică, de către Duhul Sfânt ${ }^{26}$, Cel care preface pâinea şi vinul în Trupul şi Sângele lui Hristos, Jertfa cea reală şi adevărată (nu ca cele simbolice din Vechiul Testament). Prin împărtăşirea fiecărui credincios de roadele jertfei Mântuitorului Hristos (Rom. 10, 19) ${ }^{27}$, lucrarea mântuitoare este mereu actuală, având deci un început în veşnicie și o realizare în timp.

\section{Concluzii}

Taina mântuirii noastre ne este revelată prin Biserică ${ }^{28}$. Noi afirmăm că Hristos S-a făcut om, pentru a rămâne veşnic cu noi. Chiar după înviere, prin Trupul Lui înviat, pătrunde în noi ${ }^{29}$. Iar, dacă prezența Lui în mijlocul ucenicilor, după înviere, nu s-a lăsat aşteptată la uşile încuiate, pentru că a trecut prin ele, cu cât mai mult Hristos Se află în noi atunci când îl primim ca pâine cerească, prin ceea ce El Însuşi a zis că este Trupul şi Sângele Lui, în Sfânta Euharistie.

Așadar, după cum se vede și în capitolul 2, marea taină a smereniei creştine, arătarea Domnului în Trup, se realizează în chip mistic prin prefacerea minunată a darurilor euharistice în Trupul şi Sângele Său.

${ }^{24}$ Ioan Turcu, ,Sfintele Taine şi faptele bune în mântuire. Principialităţi de fiinţă, de funcţie şi de raport”, în Studii Teologice, nr. 5-6/ 1959, p. 320.

25 Dumitru Staniloae, „Fiul şi Cuvântul lui Dumnezeu, Cel întrupat ca Om, Reunificatorul creaţiei în El pentru veci”, în Mitropolia Olteniei, nr. 4/1987, p. 22.

${ }^{26}$ Sava GHEORGHe, „Moartea şi învierea lui Hristos, temeiuri ale dreptei credinţe”, în Ortodoxia, nr. 2/1988, p. 114.

${ }^{27}$ Dumitru Viezuianu, „Moartea şi învierea Mântuitorului după Epistolele pauline”, în Studii Teologice, nr. 9-10/1977, p. 661.

${ }^{28}$ Vladimir Lossky, Teologia mistică a Bisericii de Răsărit, p. 93.

29 Dumitru Stănilone, Cuvinte de folos - Duhovnici români în dialog cu tinerii, Bucureşti, Edit. Bizantină, 1999, p. 16. 
În capitolul 3 am arătat că, doar în Sfânta Euharistie primim sub forma pâinii şi a vinului, adevăratul Trup şi Sânge al lui Hristos, devenim comunicanţi cu esența dumnezeiască umană a Domnului şi ne facem asemenea Lui, sfinţindu-ne şi primind mărturia sau chezăşia nemuririi.

Iar în ultimul capitol al acestui studiu am evidențiat faptul că, unirea noastră personală cu Mântuitorul se realizează prin Euharistie. Această unire ne menţine viaţa personală şi responsabilă în faţa lui Dumnezeu şi ne oferă opţiunea de a spori permanent în Hristos, Dumnezeu întrupat. Fiecare împărtăşire reprezintă o inedită intâlnire, legătură şi unire cu Hristos Dumnezeu, o ascensiune importantă în întâlnirea şi comuniunea cu Hristos Însuşi şi cu aproapele nostru, ca împreună mădulare ale lui Hristos.

\section{Referințe bibliografice:}

1. ANDREICUT, Ioan, „Pietismul sectant - îndepărtarea de la credinţa creştină", în Ortodoxia,nr. 1/1989, p. 54-63;

2. CABASILA, Nicolae, Despre viața în Hristos, traducere din limba greacă şi note de Teodor Bodogae, Bucureşti, EIBMBOR, 1997;

3. Sfântul ChIRIL al Ierusalimului, Catehezele, traducere de Dumitru Fecioru, București, EIBMBOR, 1943;

4. Clement, Olivier, Puterea credinţei, traducere de Alexandrina Andronescu și Daniela Ciascai, Târgovişte, Edit. Pandora, 1999;

5. Evdochimov, Paul, Cunoaşterea lui Dumnezeu în tradiția răsăriteană, traducerea, prefața şinotele de Vasile Răducă, Bucureşti, Edit. Christina, 1995;

6. GANEA, Ioasaf, „Taina Sfintei Euharistii, mijloc de mântuire”, în Mitropolia Moldovei şi Sucevei, nr. 5/1988, p. 66-70;

7. GHEORGHE, Sava, „Moartea şi învierea lui Hristos, temeiuri ale dreptei credinţe", în Ortodoxia, nr. 2/1988, p. 103-114;

8. LOSSKY, Vladimir, Teologia mistică a Bisericii de Răsărit, traducere de Vasile Răducă, București, Edit. Bonifaciu, 1998;

9. MiHĂLCESCU, Ioan, Dogmatica iubirii, col. „Clasici ai teologiei românești”, București, Edit. România Creștină, 1998;

10. NICOLAE al Makariopolei, „Prênchipuiri euharistice, caracterul şi importanța lor", în Mitropolia Banatului, nr. 1-3/1974,p. 29-34; 
11.PoGAN, Dorel, „Semnificaţia eclesiologică a Sfintei Euharistii”, în Studii Teologice, nr. 7-8/1973, p. 534-545;

12. STĂNILOAE, Dumitru, Cuvinte de folos - Duhovnici români în dialog cu tinerii, Bucureşti, Edit. Bizantină, 1999;

13. StĂNILOAE, Dumitru, „Fiul şi Cuvântul lui Dumnezeu, Cel întrupat ca Om, Reunificatorulcreaţiei în El pentru veci”, în Mitropolia Olteniei, nr. 4/1987, p. 7-24;

14. StĂnilOAE, Dumitru, „Teologia Euharistiei”, în Ortodoxia, nr. 3/1969, p. 343-363;

15. STOICA, Ion, „Unirea credinciosului cu Hristos prin Sfintele Taine”, în Mitropolia Moldovei şi Sucevei, nr. 3-6/1979, p. 278-291;

16. TURCU, Ioan, „Sfintele Taine şi faptele bune în mântuire. Principialităţi de fiinţă, de funcţie şi de raport”, în Studii Teologice, nr. 5-6/ 1959, p. 314-330;

17. VIEZUIANU, Dumitru, „Moartea şi învierea Mântuitorului după Epistolele pauline", în Studii Teologice, nr. 9-10/1977, p. 660-671;

18.ZIZIOULAS, Ioannis, Fiinţa eclesială, tra ducere de Aurel Nae, Bucureşti, Edit. Bizantină, 1996. 